\title{
FRACTIONATION AND BIOAVAILABILITY OF PHOSPHATES IN LACUSTRINE SEDIMENTS: A REVIEW.
}

\author{
H. L. Golterman ${ }^{1}$ \\ 'Association "Leiden-Camargue" Arles. Chemin de Tintarlot 5, F-13200 Arles (France). golterman@wanadoo.fr
}

\begin{abstract}
Phosphate bound onto sediments still plays an important role in lake metabolism. Therefore, knowledge of the different compounds in sediments and their availability for algae is essential to control their growth.

In this review different methods to fractionate phosphate in sediments of lakes and marshes are compared. The methods are operationally defined extractions with $\mathrm{NaOH}$ followed by $\mathrm{HCI}$, an extraction with dithionite in bicarbonate with or without citric acid, or functional extractions with chelating agents such as NTA and EDTA. By complexing the NTA or EDTA with Ca these chelators dissolved only the $\mathrm{Fe}(\mathrm{OOH})$ adsorbed phosphate.

It is shown that the operational extractions do not identify specific compounds such as ironhydroxide bound or Ca bound phosphate. The chelators, such as NTA or EDTA are more specific, can be used at the pH of the sediment, but have certain practica1 disadvantages. In sediments rich in organic matter, EDTA extracts also a certain amount of organic phosphate, the identity of which is unknown. $\mathrm{NaOH}$ as extractant gives the worst possible results as it incompletely dissolves iron bound phosphate and attacks an important quantity of organic phosphate. The quantity of phosphate extracted depends on the concentration of the $\mathrm{NaOH}$ and the duration of the extraction. Furthermore, during the extraction formation of $\mathrm{CaCO}_{3} \approx \mathrm{P}$ is shown to take place. Thus, the organic pool is underestimated and the inorganic one overestimated. It is shown that for each extraction it must be checked whether a second extraction yields again some phosphate - this appears even to be the case with $\mathrm{NaOH}$. After the extractions of inorganic phosphate some organic phosphates can be isolated such as humic- or fulvic bound phosphate and phytate. These compounds cannot be isolated and studied when $\mathrm{NaOH}$ is used.

Bioavailability studies have shown that different quantities of phosphate in sediments can be uced for phytoplankton growth. In this review different methods are compared and it is shown that the best method is to mix the algae with sediments and to do cell counting under the microscope. The cultures must be aerated in order to avoid an increase in $\mathrm{pH}$. Usually the sum of iron- and calcium bound phosphates is available for the algae, unless the latter compound is in the form of detrital rock particles. Biogenic 'apatite' is available for the phtyplankton species tested. The chemical fractionation of the different forms of apatite is still difficult.
\end{abstract}

Key words: phosphate, sediments, bio-availability, fractionation, chelators

\section{RESUMEN}

El fosfato acumulado en el sedimento aún juega un importante papel en el metabolismo de los lagos. Además, el conocimiento de los diferentes compuestos en los sedimentos y su disponibilidad para las algas es esencial para el control de su crecimiento.

En esta revisión se comparan diferentes métodos de fraccionamiento del fosfato de los sedimentos de lagos y marismas. Los métodos son extracciones operacionalmente definidas con $\mathrm{NaOH}$ seguidas por $\mathrm{HCl}$, una extracción con ditionita en forma de bicarbonato con o sin ácido cítrico, o extracciones funcionales con agentes quelantes tales como NTA y EDTA. Mediante la formación de complejos con el $\mathrm{Ca}$, los queladores NTA o EDTA disuelven solo el $\mathrm{Fe}(\mathrm{OOH})$ absorbido en el fosfato.

Se ha demostrado que las extracciones operacionales no identifican compuestos específicos tales como el hidróxido de hierro o de $\mathrm{Ca}$ asociado al fosfato. Los quelantes, tales como NTA o EDTA son más específicos, pueden ser usados al pH del sedimento, pero tienen ciertas desventajas prácticas. En sedimentos ricos en materia orgánica, EDTA extrae también una cierta cantidad de fosfato orgánico cuya identidad es desconocida. El NaOH como extractante da los peores resultados posiblesta que disuelve de forma incompleta el hierro asociado al fosfato y ataca a una cantidad importante del fosfato orgánico. La cantidad de fosfato extraido depende de la concentración del $\mathrm{NaOH}$ y de la duración de la extracción. Además, durante la extracción se ha observado que tiene lugar la formación de $\mathrm{CaCO}_{3} \approx$ P. Por ello, el conjunto orgánico es subestimado y el inorgánico sobrestimado. Se ha observado que para cada extracción se debe comprobar si una segunda extracción libera de nuevo algo de fosfato - esto parece ser el caso cuando se usa $\mathrm{NaOH}$. Después de las extracciones del fosfato inorgánico algunos fosfatoc 
pueden ser aislados en forma de fosfato húmico o fúlvico y fitato. Estos compuesto no pueden ser aislados y estudiados cuando se usa $\mathrm{NaOH}$.

Los estudios de biodisponibilidad han mostrado que diferentes cantidades de fosfato del sedimento pueden ser usados para el crecimiento del fitoplancton. En esta revisión se comparan diferentes métodos y se muestra que el mejor método es mezclar las algas con sedimentos y realizar contajes con el microscopio. Los cultivos pueden ser aireados con el fin de evitar un incremento del pH. Usualmente la suma de fosfatos asociados a hierro y calcio son disponibles para las algas, a menos que el último compuesto este en forma de partículas detríticas de rocas. El apatito biogénico es disponible para las especias de fitoplancton que se han comprobado. El fraccionamiento químico de las diferentes formas de apatito es aún difícil.

Palabras clave: fosfato, sedimentos, biodisponibilidad, fraccionamiento, quelantes.

\section{INTRODUCTION}

In the early sixties it became clear that only part of the phosphate and nitrogen compounds entering lakes appeared in the water outlets. In shallow lakes very little or nothing appeared in the outlets, suggesting that sediments were the cause of this problem. Water managers thought this favourable as they claimed that in this way sediments were active against eutrophication. The misleading term 'sediments as permanent sinks' originated from this concept. The processes were different for $\mathrm{N}$ and $\mathrm{P}$. At the time the loss of $\mathrm{N}$ was not fully understood: denitrification in $\mathrm{O}$, rich waters seemed unlikely and no other hypothesis was advanced. The loss of phosphate was soon recognized to be due to chemical fixation in the sediments. The influence of sediments in shallow waters on the concentrations of $\mathrm{P}$ and , therefore, on primary production, is relatively large compared with the direct input by tributaries.

$\mathrm{P}$ and even $\mathrm{N}$ release from sediments was gradually noticed, but not understood chemically. The concept of sediments as 'permanent sinks' remained, because concentrations of dissolved $\mathrm{N}$ and $\mathrm{P}$ compounds in the shallow lakes remained low. However, algal blooms became apparent. Obviously the possibility of sediments permitting algal growth had to be tested and, as in that period $\mathrm{P}$ was considered to be the dominant factor in eutrophication, experiments were set up to test the potential bioavailability of $\mathrm{P}$ in sediments for phytoplankton. Thus, Golterman et al . (1969) showed that sediments from Lake Vechten (a gyttja kind) and Lake Loosdrecht (humic rich) supported the growth of the alga Scenedesmus obliquus and it was found that the percentage of Tot-P available to the algae varied between $30 \%$ (L. Vechten) and $7 \%$ (L. Loosdrecht). As this indicated different chemical compounds in these muds we realized that a chemical fractionation was needed. In the first instance we choose the fractionation with $\mathrm{NaOH}$ and $\mathrm{HCI}$ which was a standardized method in agricultura1 research to distinguish between different P-compounds. We found, however, that the fractions obtained were in no way related to the quantity of $\mathrm{P}_{\mathrm{aa}}$. A second difference was found: while with Lake Vechten sediments algal growth reached a plateau after about 3 weeks, growth continued with Loosdrecht sediments, although slowly. I think this continued, slow growth was caused by a slow degradation of organic phosphates. Even if this

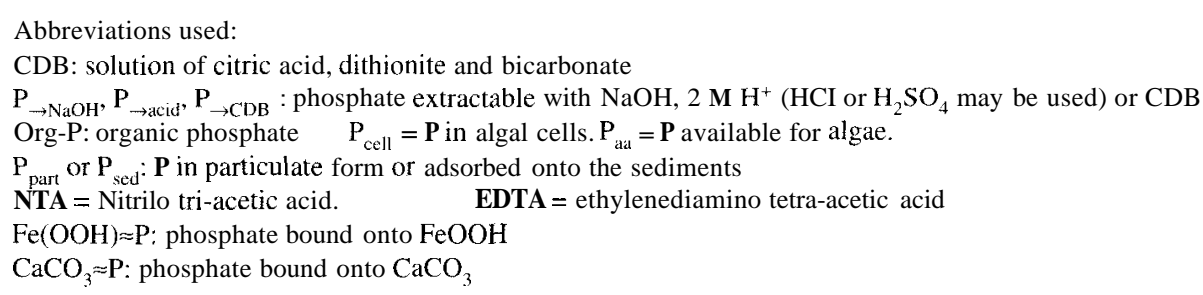



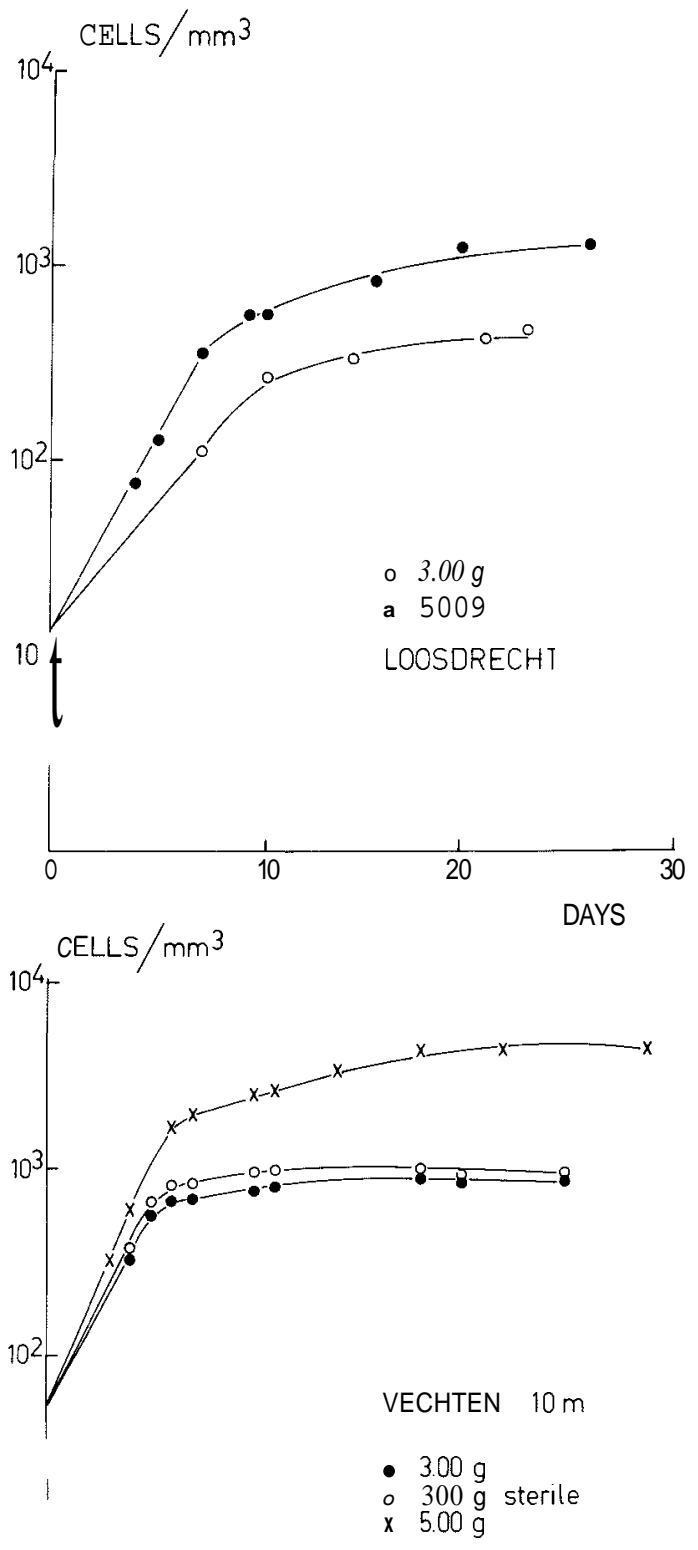

Figure 1. Growth of Scenedesmus cells on culture solutions with mud from L. Vechten \& L. Loosdrecht as sole source of phosphate. (Golterman et al.,1969). Crecimiento de células de Scenedesmus en medios de cultivo con sedimento de $L$. Vechten y L. Loosdrecht como única fuente de fosfato. (Goltermun et al.,1969). growth amounts to only a few percent per week, it might mean a considerable increase in $\mathrm{P}$ availability after e.g. 3 months. Careful inspection of the growth curves may indicate this kind of process.

It became clear, however, that sediments are no sink for $\mathrm{P}$, while the issue remained open for N-compounds.

\section{BIOAVAILABILITY}

Golterman et al. (1969) set up the first bio-assays with sediments as follows: A culture solution was made containing all the elements needed for algal growth except phosphate. A few grams of wet, fresh sediment were added in suspension and Scenedesmus obliquus was inoculated at rather low cell densities. Growth was monitored every day till it came to a standstill with Vechten sediments, while for Lake Loosdrecht the same period was chosen, although some growth still occurred. Cell numbers obtained were directly related to the amount of mud used and sterilization did not influence the amount of cells obtained, showing that the bioavailable fraction was mainly inorganic-P. An example is given in figure 1. Celis were counted in a normal blood cell counting chamber under a microscope with low magnification. Using the improved Neubacher cell counting chamber cell counting is easy: it takes about $10 \mathrm{~min}$ and the mud particles do not present difficulties. Electronic cell counters take more time and difficulties are encountered with the mud particles, while the microscopic examination gives information about the health of the cells at the same time. An alternative method is to measure the concentration of chlorophyll a, but we found this less reliable as the chlorophyll a content per cell depends on the light intensity, and cultures tend furthermore to become yellow at the end of their growth, without P-losses. The resulting cell count was converted into $\mathrm{P}_{\text {cell }}$ by using a calibration curve made with cells growing on $\mathrm{KH}_{2} \mathrm{PO}_{4}$.

We did a few experiments with the mud enclosed in dialysis tubes (Golterman, 1977), 
but found a very poor growth, even with $\mathrm{KH}_{2} \mathrm{PO}_{4}$ added, compared to mud without these tubes. This is not due to the need for physical contact, but to the fact that the $\mathrm{P}$ is so strongly adsorbed onto the sediments that the diffusion through the dialysis tube became virtually zero. This was demonstrated by adding $\mathrm{KH}_{2} \mathrm{PO}_{4}$ to the mud suspensions, after which poor growth was again obtained.

Bruning \& Klapwijk (1984) modified the method for measuring the concentration of chlorophyll a by developing a derivative spectroscopic method to measure growth of algae in mud suspensions. It compensates for the loss of sensitivity due to turbidity caused by the sediments. In principle the chl a concentration is measured; the method therefore has the same disadvantage a5 the direct chl a determination. Klapwijk \& Bruning (1984), using this method to estimate the percentage of $\mathrm{P}_{\mathrm{aa}}$ in severa1 Dutch lakes, found a high variability. Their results, however, cannot be compared with specific P-fractions as no fractionation was carried out. The results were used to predict in which lakes P-removal from the inlet would be most useful.

Grobler \& Davies (1979, 1981) have shown that NTA-extractable $\mathrm{P}$ in sediments of rivers and reservoirs in South Africa was strongly correlated $(r=0.97)$ with $\mathrm{P}_{\mathrm{aa}}$ for Selenastrum capricornutum, but the $\mathrm{P}_{\text {aa }}$ was 5 times higher than the NTA-extractable P. (It is possible that this difference was due to the interference of NTA with the P-determination).

Grobbelaar (1983) has shown for sediments in the Amazon river that the $\mathrm{P}_{\text {part }}$ was available to algae. As the Amazon river has low $\mathrm{Ca}^{2+}$ concentrations most of the $P_{\text {part }}$ was probably in the form of $\mathrm{Fe}(\mathrm{OOH}) \approx \mathrm{P}$.

Most work on bioavailability has been done on calcareous sediments. Except for one report (Golterman et al. 1969) on Loosdrecht Lake sediments, very little work has been done on organic, or humic rich sediments. Figure 1 shows that in such a case slow growth in the bio-assay may occur and may lead to wrong results. 1 expect that more work on different types of sediments may yield important results. The bioavailability of
org-P needs experiments over longer periods with a careful fractionation of $\mathrm{P}_{\text {sed }}$.

It is possible to define some criteria which must be met in order to ensure that bio-assay results are meaningful. The most important ones seem to be:

1) Sufficient cell increase should be obtained. In the control culture (without mud) the final cell number must be at least 300 times the inoculum (this means at least 8 cell divisions, which in practical terms means an experiment lasting at least 8 days).

2) During growth, in order to prevent apatite formation, no important $\mathrm{pH}$ increase must occur. This means that $\mathrm{CO}$, must not be the growth limiting factor, but should be supplied in excess. The cultures must, therefore, be intensively aerated.

3) A constant cell level at the end of the experiment is desirable. This may not be obtainable in organic (= humic) rich sediments, but this gives then an indication of the problem of slow mineralization of org-P.

4) During at least a short period an exponential growth rate should be obtained.

\section{FRACTIONATION OF P-COMPOUNDS}

\section{Fractionation of inorganic P-compounds}

The first fractionation scheme of P-compounds in soils is that of Chang \& Jackson (1957, see also Jackson, 1958) using $\mathrm{NaOH}$ and $\mathrm{HCl}$, while later a $\mathrm{NH}_{4} \mathrm{~F}$ extraction step was added. Fluoride was later omitted as it may induce the formation of fluor-apatite.

The Chang \& Jackson procedure was slightly modified by Hieltjes \& Lijklema ('H\&L"; 1980). They introduced a first step with $\mathrm{NH}_{4} \mathrm{Cl}$, which is supposed to extract the 'loosely bound-P". The chemical quality of this fraction is not clear, it is probably o-P from the interstitial water; it is usually only a few percent of Tot-P. Neither the duration of the $\mathrm{NaOH}$ extractions (17 hr) nor the concentration of the $\mathrm{NaOH}$ were tested and no 

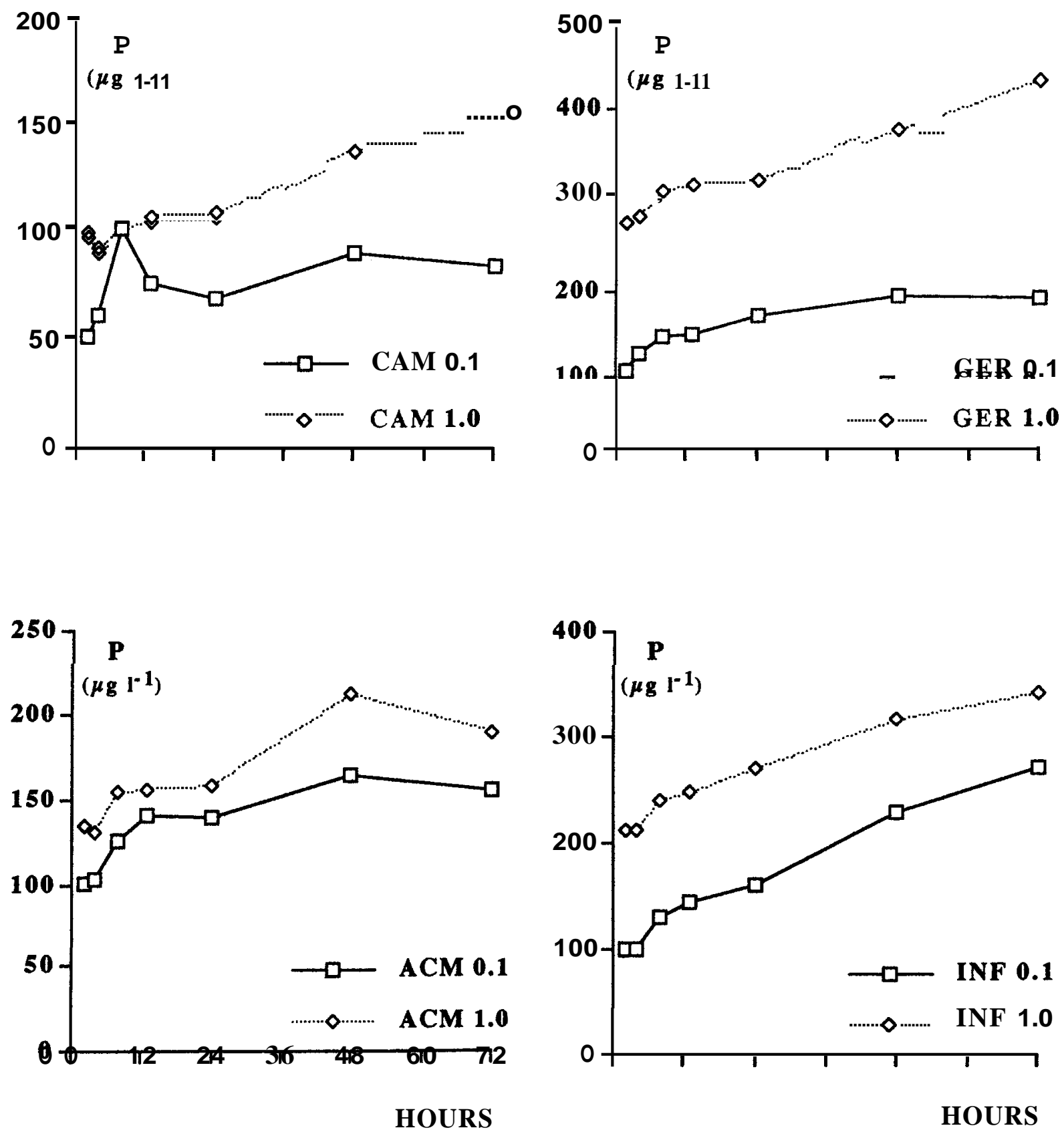

HOURS

Figure 2. Influence of the extraction time and $\mathrm{NaOH}$ concentration on the amount of $\mathrm{P}$ extracted $\left(\mu \mathrm{g} \mathrm{l^{-1 }}\right)$. Two samples rich in org-C, but poor in $\mathrm{Ca}$; sediments from the Parque Doñana (Infraqueable and Acebuche de Matalascañas ('INF and 'ACM") and one rich in org-C with medium $\mathrm{Ca}$ from a nearhy reservoir, El Gergal ('GER"), and one poor in org-C, but rich in Ca from a marsh in the Camargue ('CAM'). (Golterman $e t$ al., 1998.). Influencia del tiempo de extracción y de la concentración de $\mathrm{NaOH}$ sobre la cantidad de P extraido ( $\mu \mathrm{g} l^{-1}$ ). Dos muestras ricas en C-org, pero pobres en Ca, sedimentos de Parque de Doñana (Infranquable y Acebuche de Matalacañas [INF y ACM] y una rica en C-org con concentración media de Ca de un embalse próximo, El Gergal [GER], y una pobre en C-org, pero rica en Ca de una marisma en la Camargue [CAM]). (Golterman et al., 1998.). 
checks were made to estimate the recovery of added standard compounds. It is not clear why the shaking time for the extraction of $\mathrm{P} \rightarrow \mathrm{NaOH}$ is always set at $17 \mathrm{hr}$, as the $\mathrm{P}$ from the $\mathrm{Fe}(\mathrm{OO} \mathrm{OH}) \approx \mathrm{P}$ complex will be dissolved in a much shorter time - except that $17 \mathrm{hr}$ is convenient for overnight experimenting.

Williams et al. $(1976,1980)$ used an extraction method with citric acid, dithionite plus bicarbonate ("CDB"), at a relatively high $\mathrm{pH}$, followed by $\mathrm{NaOH}$. The CDB is supposed to extract the $\mathrm{Fe}(\mathrm{OOH}) \approx \mathrm{P}$ which leaves only org-P for the $\mathrm{NaOH}$ step. A subsequent extraction with $\mathrm{HCl}$ is supposed to extract $\mathrm{CaCO}_{3} \approx \mathrm{P}$. The Williams extraction was later changed by omitting the CDB step by the Geneva group (Favarger, pers. comm.) and the C. C. 1. W. group (Manning, pers. comm.), but out of deference the name of the procedure was not changed. The reason for this change was the assumption that $\mathrm{P}_{\rightarrow \mathrm{NaOH}}$ reflects better than $\mathrm{P}_{\rightarrow \mathrm{CDB}}$ the $\mathrm{P}_{\mathrm{aa}}$.

For a long time it was not realized that $\mathrm{NaOH}$ does the same as $\mathrm{NH}_{4} \mathrm{~F}$, but now inducing the formation of hydroxyl-apatite (Golterman \& Booman, 1988; De Groot \&Golterman, 1990). These authors furthermore not only showed that apatite formation leads to wrong results, but also that $\mathrm{NaOH}$ hydrolyses a certain quantity of the org-P. From Table 1 it can be seen that $\mathrm{NaOH}$ extracts more than $\mathrm{Fe}(\mathrm{OOH}) \% \mathrm{P}$ only, and that $\mathrm{CaCO} 3 \% \mathrm{P}$ is formed. Several modifications of the $\mathrm{NaOH} \& \mathrm{HCl}$ extractions have been published that will not be discussed here, as most have the same problems as outlined in Golterman \& Booman ('G\&B'; 1988) and De Groot \& Golterman (1990). $\mathrm{NaOH}$ extractions were once more invalidated by Golterman (1996), Golterman et al . (1998) and by Romero-Gonzalez et al . (2001). All thece authors demonstrated that the duration of the extraction and the concentration of the $\mathrm{NaOH}$ always influence the quantities of $\mathrm{P}$ extracted and therefore do not produce a specific fraction. Figure 2 and Table 2 show the influence of the extraction time and the concentration of the $\mathrm{NaOH}$. It can be seen that the concentration of extractable $\mathrm{P}$ increased with time in some cases, but decreased in others. The decrease is caused by re-adsorption onto $\mathrm{CaCO}_{3}$, while the increase is due to the hydrolysis of the org-P. Decrease or increase depend, therefore, on the relative concentration of these compounds. The occurrence of these processes can be demonstrated by comparing extraction results from $H \& L$ with G\&B (Table 2). The hydrolysis of org-P was already mentioned by Bostrom et al. (1988), but as these authors presented no chemical evidence, it never received much attention. Petterson et al. (1988) gave an overview of different operational ${ }^{1}$, chemical extractions, without comparison of these methods, while factors like duration, number of, and influence of the $\mathrm{NaOH}$ concentration were not examined. Extractions with chelators were mentioned only. The latter authors do, however, mention that these methods cannot be used for identification of discrete Pcompounds.

Table 1. Amounts of $\mathrm{Fe}(\mathrm{OOH}) \approx \mathrm{P}, \mathrm{CaCO}_{3} \approx \mathrm{P}$, org-P and their sum $(\Sigma \mathrm{P})$ in 3 sediments from Camargue marshes and 2 sedinients from Lake Balaton ( $\mathrm{P}$ in $\mu \mathrm{g} \mathrm{g}^{-1} \mathrm{dw}$.). From De Groot \& Golterman, 1990. Cantidades de $\mathrm{Fe}(\mathrm{OOH}) \approx P, \mathrm{CaCO} \approx \mathrm{z}$, org-P y su suma $(\Sigma-P)$ en 3 sedimentos de la Camarga y 2 sedimentos del Lago Balaton ( $p$ en in $\mu g g^{-l} d w$ ). Según De Groot \& Golterman, 1990.

\begin{tabular}{|c|c|c|c|c|c|c|c|c|c|}
\hline Marsh & $\begin{array}{c}\mathrm{Fe}(\mathrm{OOH})=\mathrm{P} \\
(\mathrm{G} \& \mathrm{~B})\end{array}$ & $\begin{array}{l}P_{\rightarrow \mathrm{NaOH}} \\
(\mathrm{H} \& \mathrm{~L})\end{array}$ & $\begin{array}{c}\mathrm{CaCO3} \approx \mathrm{P} \\
(\mathrm{G} \& \mathrm{~B})\end{array}$ & 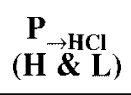 & $\begin{array}{c}\text { Org-P } \\
(G \& \text { \& })\end{array}$ & $\begin{array}{c}\text { Org-P } \\
(\text { H \& L) }\end{array}$ & $\begin{array}{c}\sum-\mathbf{P} \\
(\mathbf{G} \& \mathbf{B})\end{array}$ & $\begin{array}{c}\Sigma-P \\
(H \& L)\end{array}$ & Tot-P \\
\hline Relongue 1 & 228 & 20 & 245 & 539 & 267 & 177 & 740 & 736 & 709 \\
\hline Relongue II & 147 & 47 & 230 & 410 & 322 & 280 & 699 & 737 & 747 \\
\hline Ricefield I & 78 & 12.5 & 271 & 423 & 373 & 163 & 722 & 599 & 746 \\
\hline Ricefield II & 82 & 5.3 & 303 & 421 & & & & & \\
\hline Id. +162 & 190 & 3.5 & 350 & 575 & & & & & \\
\hline Balaton $\mathrm{T}$ & 30 & 16 & 112 & 268 & 280 & 121 & 420 & 406 & 433 \\
\hline Balaton $\mathrm{K}$ & 102 & 42 & 216 & 346 & 297 & 171 & 61.5 & 559 & 627 \\
\hline
\end{tabular}


Table 2. Influence of the $\mathrm{NaOH}$ concentration and extraction time in the "H\&L" extraction on the amount of P extracted. Data from sediments from a marsh in the Parque Doñana and from El Gergal and a marsh in the Camargue. Results expressed in percentage of the $17 \mathrm{hr}$ extraction with $0.1 \mathrm{M} \mathrm{NaOH}$. (Golterman, 1996). Influencia de la concentración de $\mathrm{NaOH}$ y el tiempo de extracción en la extracción H\&L sobre la cantidad de P extraido. Datos de sedimentos en el Parque de Doñana y de El Gergal y una marisma de la Camarga. Los resultados se expresan corno un tanto por ciento de la extracción de 17 horas con NaOH 0.1 M. (Golterman, 1996).

\begin{tabular}{ccccccccccc}
\hline & \multicolumn{3}{c}{ Camargue } & \multicolumn{3}{c}{ Doñana } & \multicolumn{3}{c}{ El Gergal } \\
\hline & $17 h r$ & $24 h r$ & $45 h r$ & $17 h r$ & $24 h r$ & $45 h r$ & $17 h r$ & $24 h r$ & $45 h r$ \\
\hline $0.1 \mathrm{M}$ & 100 & 84 & 88 & 100 & 95 & 478 & 100 & 99 & 79 \\
$0.5 \mathrm{M}$ & 218 & 163 & 111 & 184 & 130 & 93 & 245 & 229 & 175 \\
$1.0 \mathrm{M}$ & 306 & 207 & 172 & 284 & 220 & 134 & 373 & 369 & 202 \\
\hline
\end{tabular}

Psenner et al . (1985) and Psenner \& Puckso (1988) re-introduced a first step with a reducing agent, i.e. dithionite, in a sodium bicarbonate solution without citric acid, and followed by $\mathrm{NaOH}$ again. The dithionite/bicarbonate extracts the $\mathrm{Fe}(\mathrm{OOH}) \approx \mathrm{P}$, but not the $\mathrm{FeOOH}$ itself, rendering subsequent steps uncertain. The $\mathrm{NaOH}$ step is supposed to extract org-P or non-reactive$\mathrm{P}$, but the problem of the hydrolysis of org-P was not fully appreciated. The next steps were with $\mathrm{HCl}$, followed by hot $\mathrm{NaOH}$. The hot $\mathrm{NaOH}$ extracted only $10 \%$ of the first (cold) $\mathrm{NaOH}$ step. It is not clear to what extent the $\mathrm{FeOOH}$ itself is removed, which is essential for further analysis.

Burke et al. (1989) used a series of extractants for 10 surface sediments from shallow bays in order to study P-fractionation. They showed that the quantities extracted increased with the extraction time in a $0.5 \mathrm{M} \mathrm{NaHCO}_{3}$ solution adjusted at $\mathrm{pH}$ 8.5. They showed furthermore a strong dependence of the quantities extracted on the ratio sediment/extractant-volume, but did not repeat the extractions; it is therefore not certain that the extractions were complete..

In none of the above mentioned methods was it checked whether a second extraction extracts any more of the target compound. We have shown that with $\mathrm{NaOH}$ this is certainly the case.

For several reasons 1 tried another approach, i.e. using chelators specific for certain com- pounds. Compounds like NTA and EDTA will solubilize $\mathrm{Ca}$ and $\mathrm{Fe}$ compounds by complexation, and this can be done at a pH identical to that of the sediment in question. NTA complexed in advance with $\mathrm{Ca}^{2+}$ will not be able to attack $\mathrm{Ca}-$ salts; this extractant becomes specific for $\mathrm{Fe}(\mathrm{OOH}) \approx \mathrm{P}$ :

$\mathrm{CaCO}_{3} \approx \mathrm{P}+\mathrm{Fe}(\mathrm{OOH}) \approx \mathrm{P}+\mathrm{NTA}--->\mathrm{Ca}-\mathrm{NTA}+$ Fe-NTA + o-P

but

$$
\begin{aligned}
& {\left[\mathrm{CaCO}_{3} \approx \mathrm{P}\right]+\mathrm{Fe}(\mathrm{OOH}) \approx \mathrm{P}+\mathrm{Ca}-\mathrm{EDTA}--->} \\
& {\left[\mathrm{CaCO}_{3} \approx \mathrm{P}\right]+\mathrm{Fe}-\mathrm{EDTA}+\mathrm{o}-\mathrm{P}}
\end{aligned}
$$

In theory EDTA should work better than NTA, resulting in a more stable complex. This appeared, however, not to be the case, NTA giving better results. Nevertheless the extraction was time consuming, the kinetics were slow probably due to the reaction rate of the formation of the Fe-chelator complex, which is even much slower with EDTA. As the reduction of $\mathrm{Fe}(\mathrm{OOH})$ by reducing compounds is much quicker, 1 tried extractions with Ca-NTA plus ascorbic acid or $\mathrm{NH}_{2} \mathrm{OH}$ (Golterman, 1982). These reducing agents are only active at a slightly acid $\mathrm{pH}$, therefore the extractions were made at $\mathrm{pH}=5$. The results were very promising, o-P added to a

\footnotetext{
${ }^{1}$ i.e. extractions defined by the extraction method, and not by the target compound
} 
Camargue soil was quantitatively recovered as $\mathrm{Fe}(\mathrm{OOH}) \approx \mathrm{P}$ or $\mathrm{CaCO}_{3} \approx \mathrm{P}$ and, because of the short duration of the extractions, no apatite was solubiíized in the first step. Ascorbic acid has the disadvantage that after some time a precipitate appears with the $\mathrm{Ca}$ from the Ca-NTA, and $\mathrm{NH}_{2} \mathrm{OH} . \mathrm{HCl}$ that it works only at $\mathrm{pH}$ not far from 5. Therefore we also tried dithionite $\left(\mathrm{Na}_{2} \mathrm{~S}_{2} \mathrm{O}_{2}\right)$ as reducing agent, which compound is the only one reducing at a $\mathrm{pH}=8$. The results were satisfactory (Golterman \& Booman, 1988). Artificially prepared suspensions of $\mathrm{Fe}(\mathrm{OOH}) \approx \mathrm{P}$ and $\mathrm{CaCO}_{3} \approx \mathrm{P}$ were quantitatively recovered, even when added to Camargue soils. As NTA combined with dithionite was not a better extractant than EDTA and as the extracting capacity could be increased with EDTA, Golterman (1996) later changed the Ca-NTA $(0.02 \mathrm{M})$ to Ca-EDTA $(0.05 \mathrm{M})$. The extractions were repeated till the target compounds were depieted. This is needed as reactions (1) and (2) are equilibrium processes and will not extract $100 \%$ in one step. (This is the only method in which this repetition is done).

Ruttenberg (1992) developed the SEDEX extraction sequence, using in principle citrate/ dithionite/bicarbonate followed by Na-acetate $(\mathrm{pH}=4)$ and finally $\mathrm{H}_{2} \mathrm{SO}_{4}$. Between the different steps washings with $\mathrm{MgSO}_{4}$ were added. Na-acetate is supposed to extract only the biogenic $\mathrm{CaCO}_{3} \approx \mathrm{P}$, and $\mathrm{H}_{2} \mathrm{SO}_{4}$ the detrital (bouldery) apatite $\mathrm{Ca}_{5}(\mathrm{PO} 4)_{3} \mathrm{OH}$. Golterman (1996) found, however, that EDTA extracted a larger quantity of $\mathrm{CaCO}_{3} \approx \mathrm{P}$ from Camargue sediments than the Na-acetate plus $\mathrm{H}_{2} \mathrm{SO}_{4}$. The difference was $423 \mu \mathrm{g} \mathrm{g} \mathrm{g}^{-1}$ against $330 \mu \mathrm{g} \mathrm{g} \mathrm{g}^{-1}$ (with a Tot-P = $0.97 \mathrm{mg} \mathrm{g}^{-1}$ ), which difference is at the moment not understood.

There are several more fractionation methods. e.g. House et al . (1995) used the iron-oxide stripping method, which might be promising as a fractionation method, with the difficulty that several extractions may be necessary, as tailing may occur. A similar approach has been made by Huettl et al . (1979). They loaded a cationexchange column with aluminium hydroxide, measured the amount of phosphate adsorbed, and defined this as $\mathrm{P}_{\text {aа }}$. When using these techniques several possible sources of errors must be identified first: incomplete transfer of $\mathrm{P}$ to the exchanger, slow dissolution of $\mathrm{P}_{\text {part }}$, incomplete retrieval from the exchanger, etc (Waller \& Pickering, 1992). The conditions of these extractions must, therefore, be carefully checked - which is not often done.

1 foresee that in future the extractions with chelators will be further improved, e.g. by the use of chelators specific for $\mathrm{Ca}^{2+}$ or $\mathrm{Fe}^{3+}$. Our first attempts were promising but we did not pursue this method as the specificity depended on the $\mathrm{pH}$, which must be adjusted to the $\mathrm{pH}$ of the sediments.

Two papers compared different extraction procedures. Using Doñana sediments, synthetic compounds and unicellular algae, Jáuregui \& García Sanchez (1993) compared 4 fractionation schemes: the Williams et al . $(1971,1976)$, the Hieltjes \& Lijklema (1980), the Golterman \& Booman ("GB";1988) and a modification of this, using citric acid instead of the Ca-NTA plus $\mathrm{Na}_{2}{ }^{-}$ EDTA extractions. This modification can only be used if no distinction is needed between $\mathrm{Fe}(\mathrm{OOH}) \approx \mathrm{P}$ and $\mathrm{CaCO}_{3} \approx \mathrm{P}$. They concluded that chelators, like citric acid, are good tools for the study of P-fractionation - citric acid can be used if no distinction between $\mathrm{Fe}(\mathrm{OOH}) \approx \mathrm{P}$ and $\mathrm{CaCO}_{3} \approx \mathrm{P}$ is needed.

Barbanti et al . (1994) compared 7 different extraction schemes, both theoretically and practically, and concluded that chelators gave the best results. They found that in the SEDEX method re-adsorption was significant, but that the GB method gave an incomplete extraction of detrital apatite. In this respect the SEDEX method is superior to the (old) NTA/EDTA method. In the present EDTA method this apatite will now of course appear as org- $\mathrm{P}_{\rightarrow \text { acid }}$, previously called ASOP (acid soluble org-P), as an acid extraction follows the EDTA extractions (De Groot, 1990).

In the "cold $\mathrm{NaOH}$ " extracts some phosphate appears from certain sediments which does not react with the blue/molybdate method. It has been suggested that this might be a polyphosphate (Hupfer et al., 1995), but the evidence is rather weak and it is more likely that phytate or 
humic-P form this pool (Golterman et al., 1998). See below, page 23 .

\section{Fractionation of organic P-compounds}

The fractionation of org-P is much less developed than that of inorg-P. Several authors (among which myself) used enzymatic methods to identify specific target compounds. However, if in a preceding step the $\mathrm{FeOOH}$ and/or the $\mathrm{CaCO}_{3}$ are not removed from the sediments, these two compounds will adsorb the liberated o-P, so that the concentration of the target compound will be largely underestimated.

De Groot (1990) made a first step in the right direction by trying to analyse the org-P after the complete removal of the inorganic components. $\mathrm{He}$ used $\mathrm{HCl}$ as third extractant (org- $\mathrm{P}_{\rightarrow \text { acid }}$ ), after the NTA/EDTA extractions, finally followed by hot $\mathrm{NaOH}$. We do not know what is the org- $\mathrm{P}_{\rightarrow \text { acid }}$ (previously called ASOP). It may be traces left over from the EDTA extractions, it may be a small quantity of fulvic-P; we found a constant ratio $\mathrm{Fe} / \mathrm{P}$ in this extract. The quantities are, however, always small. In the hot $\mathrm{NaOH}$ extract de Groot \& Golterman (1993) identified humic-P (by precipitation) and phytate by using phytase. A difficulty with this enzyme is that the humic acid inhibits the enzyme activity, causing an underestimation. For future work it will be necessary to purify the hot $\mathrm{NaOH}$ extract first, e.g. by a mild oxidation with $\mathrm{H}_{2} \mathrm{O}_{2}$, or adsorption onto and re-dissolution from freshly added FeOOH. ${ }^{31} \mathrm{P}-\mathrm{NMR}$ is likely to be a possible way of analysing the purified, concentrated extract (Golterman, 2001).

Although the presence of humic material in the hot $\mathrm{NaOH}$ is evident, the complex of humic material and phosphate is not yet proved. Finally it must be noted that both the Ca-EDTA and $\mathrm{Na}_{2}{ }^{-}$ EDTA extracts are always dark brown; probably most of the humic material is already extracted there. As the Fe-humic complex is destroyed by EDTA, the evidence for the existence of a humic/Fe/P complex is destroyed as well. Serrano (in press) reported the presence of a brown compound plus $\mathrm{P}$ extractable with butano1 in the EDTA extracts; it is likely that the humic/Fe/P complexes are already extracted there. Part of the o-P found in the EDTA extracts may derive from these complexes.

\section{COMPARISON BETWEEN BIOAVAILABLE PAND P-FRACTION}

When comparing the $\mathrm{P}_{\mathrm{aa}}$ with the extractable $\mathrm{P}_{\text {sed, }}$, it must in the first place be understood that both procedures have been modified in the course of the years and that even under the same name different extraction methods have been used. In the literature there are even publications about "bioavailable-P", where this fraction is supposed to be equal to the quantity extracted by one extractant, e.g. strong acid. Furthermore, a 'good' correlation between the $\mathrm{P}_{\mathrm{aa}}$ and the extractable- $\mathrm{P}$ is no indication that a certain chemical fraction is bioavailable as long as the slope does not approach 1 (one). We are looking for the identity of and not for the correlation between quantities.

There are several papers where a chemical fraction is supposed to be equal to the biological one: e.g. House et al . (1995) used the iron-oxide stripping method to determine the $\mathrm{P}_{\mathrm{aa}}$ without bio-assays. If both methods are not applied, these papers are not further discussed here.

Golterman et al . (1969) found no agreement between $\mathrm{P}_{\text {aa }}$ and $\mathrm{P}_{\rightarrow \mathrm{NaOH}}$ in lake Vechten or Lake Loosdrecht, but the $\mathrm{P}_{\text {aa }}$ quantity approached the sum of the decrease in $\mathrm{P}_{\rightarrow \mathrm{NaOH}}$ plus $\mathrm{P}_{\rightarrow \text { acid }}$. This is not identical to the sum of $\mathrm{Fe}(\mathrm{OOH}) \approx \mathrm{P}$ plus $\mathrm{CaCO}_{3} \approx \mathrm{P}$ as the $\mathrm{NaOH}$ extracts contained also hydrolysed org-P. During the 3 weeks of the experiment the $\mathrm{CaCO}_{3} \approx \mathrm{P}$ may have re-equilibrated with the $\mathrm{Fe}(\mathrm{OOH}) \approx \mathrm{P}$, as both compounds are in equilibrium (Golterman, 1998). The total quantities of $\mathrm{P}_{\rightarrow \mathrm{NaOH}}$ plus $\mathrm{P}_{\rightarrow \text { acid }}$ were not depleted during the incubation, $\approx 16 \%$ and $\approx 45 \%$ had been used from L. Vechten and L. Loosdrecht muds respectively, which is due to the fact that these two pools contained also org-P, which is not bioavailable.

Using mud from 13 lakes in The Netherlands and the fractionation procedure with Ca-NTA and 
$\mathrm{Na}_{2}$-EDTA, De Graaf Bierbrauwer-Würtz \& Golterman (1989) found the following correlation between $\mathrm{X}\left(=\mathrm{Fe}(\mathrm{OOH}) \approx \mathrm{P}+\mathrm{CaCO}_{3} \approx \mathrm{P}\right)$ and

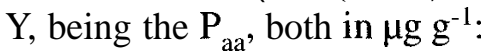

$$
\mathrm{Y}=0.97 \mathrm{X}+5.9 \quad(\mathrm{n}=14, \mathrm{r}=0.9)
$$

This correlation (Fig. 3) demonstrated the near identity of the quantities used by the algae and extracted. For Lake Vechten the extractable P was $50 \%$ of the Tot-P, a reasonable agreement with the quantity of $\mathrm{P}_{\mathrm{aa}}$ found in 1969 (44\%).

Fabre et al .(1996), using sediments from the river Garonne found that the sum $[\mathrm{Fe}(\mathrm{OOH}) \approx \mathrm{P}+$ $\mathrm{CaCO}_{3} \approx \mathrm{P}$ ] overestimated the $\mathrm{P}_{\mathrm{aa}}$. The difference with the Dutch lakes is probably due to the presente of detrital (rock) apatite which is extracted by the EDTA method, but not available for the algae in three weeks. The possibility to distinguish between these two forms of apatite using the SEDEX method (Ruttenberg, 1992) must be further explored.

Williams et al. $(1976,1980)$ used the extraction method with $\mathrm{CDB}$ followed by $\mathrm{NaOH}$. Williams stated that $\mathrm{P}_{Æ \mathrm{NaOH}}$ reflects the $\mathrm{P}_{\mathrm{aa}}$.

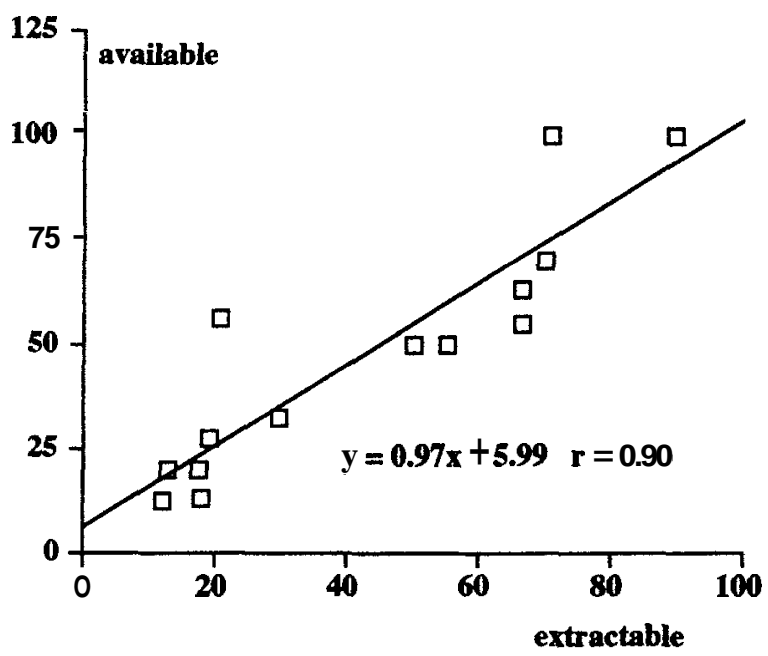

Figure 3. Phosphate availability against $\mathrm{Fe}(\mathrm{OOH}) \approx \mathrm{P}+\mathrm{CaCO}_{3} \approx \mathrm{P}$ in sediments from 13 lakes in the Netherlands and 1 marsh in the Camargue. Data in $\mathrm{P}=\mu \mathrm{g} \mathrm{g}^{-1}$. Disponibilidad de fosfato frente a cantidad de $\mathrm{Fe}(\mathrm{OOH}) \approx P+\mathrm{CaCO} \approx P$ en los sedimentos de 13 lagos en Holanda y una marisma en la Camarga. Datos en $P=\mu g g^{-1}$.
However, in Williams et al . (1980) the amount of $\mathrm{P}$ used by the algae was not measured; it was only shown that a linear correlation was found between algal growth and $\mathrm{P}_{\rightarrow \mathrm{NaOH}}$, and the yield of the algal culture used, Scenedesmus, per mg of $\mathrm{P}$ is rather low : $-20 \%$ of what could be expected. These authors stated that they did not obtain a good agreement with Ca-NTA extractions, but they used a Ca-NTA extractant during a very short time only, and without the reducing agent. Golterman et al . (1969) and Fabre et al . (1996) have shown that $\mathrm{P}_{\rightarrow \mathrm{NaOH}}$ is not equal to the $\mathrm{P}_{\mathrm{aa}}$.

Using 5 different soils, Huettl et al. (1979) compared the amount of phosphate that can be adsorbed onto $\mathrm{Al}(\mathrm{OH})_{3}$, affixed to a cation exchauge resin, in $24 \mathrm{hr}$ with the amount of $\mathrm{P}_{\text {aa }}$ for a P-starved culture of Selenastrum capricornutum. The authors concluded that the $\mathrm{P}$ removed by the raisin is, on average, $98 \%$ of $\mathrm{P}_{\mathrm{aa}}$. Several points remain, however, obscure in this paper. The quantity of exchangeable $\mathrm{P}$ depended on the duration of the extraction, the medium used and the ratio solution/soil. It is also not clear whether the quantities of $\mathrm{P}_{\text {aa }}$ were taken from an earlier study or were new results, while the amount accumulated depended on the culture duration and was still increasing after $48 \mathrm{hr}$ - no constant level was obtained. There is no information whether the cultures were aerated or not.

Dorich et al. (1984, 1985) studied P-bioavailability in 7 non-calcareous, suspended, stream sediments each taken at 4 different times and compared this quantity with several sequential extraction methods. The procedures used were: 1) $0.1 \mathrm{M}$ $\mathrm{NaOH}$ and $1 \mathrm{M} \mathrm{HCl}$; 2) $0.5 \mathrm{M} \mathrm{NH}_{4} \mathrm{~F}, 0.1 \mathrm{M} \mathrm{NaOH}$ and $1 \mathrm{M} \mathrm{HCl}$; 3) $0.01 \mathrm{M} \mathrm{NTA}$; 4) hydroxy-Al resin. The percentages extracted frorn Tot-P were $52,58.8,45$ and $17 \%$ respectively. The extraction with $\mathrm{NH}_{4} \mathrm{~F}$ (22\% of Tot-P) decreased the quantity of $\mathrm{P}_{\rightarrow \mathrm{NaOH}}$ and increased that of $\mathrm{P}_{\rightarrow \mathrm{HCl}}$. Selenastrum capricornutum was used again and incubated for 2 or $14 \mathrm{~d}$. The $\mathrm{P}_{\text {aa }}$ varied between 21 and $31 \%$ of Tot-P with an average of $25 \%$. $\mathrm{P}_{\rightarrow \mathrm{NaOH}}$ correlated strongly with $\mathrm{P}_{\text {aa }}(r=0.95)$, but overestimated the $\mathrm{P}_{\mathrm{aa}}$ with a constant amount, the regression line being: $\mathrm{P}_{\text {aa }}=0.85 \mathrm{P}_{\rightarrow \mathrm{NaOH}}-1.85$. It seems very probably that this overestimation is caused by 
the hydrolysis of non-available org-P. The resin extractable-P was much lower than $\mathrm{P}_{\text {aa }}$, while $\mathrm{P}_{\rightarrow \rightarrow \text { NTA }}$ was higher. There remain a few problems: the culture still contained o-P after $14 \mathrm{~d}$ and it seems therefore that $\mathrm{P}$ was not the limiting factor for algal growth; it is not clear whether the cultures were aerated or not - $\mathrm{pH}$ values were not given; finally, the range of $\mathrm{P}_{-\rightarrow>\mathrm{NaOH}}$ and that of $\mathrm{P}_{\mathrm{aa}}$ were very small - on a curve such as figure 1 , it would add only one point.

If, as in the new Williams method, $\mathrm{NaOH}$ is used as P-extractant, the fractionation method is not different ${ }^{2)}$ from "H\&L", which is essentially the old Chang \& Jackson method with a preliminary washing added with $\mathrm{NH}_{4} \mathrm{Cl}$ at $\mathrm{pH}=7$, the function of which is rather unclear. The "new" Williams method, therefore, need not be taken into account separately. The presence, in all sediments, of different forms of org-P which are partly hydrolysed by $\mathrm{NaOH}$ and $\mathrm{HCl}$, is often not taken into account by geochemists, although these compounds behave biologically differently from the iron- and calcium-bound phosphates.

Hosomi et al . (1981) studied P-release and Pavailability (maxirnum growth of Selenastrum capricornutum) in 4 Japanese lake sediments. They used the Chang \& Jackson extraction method, but with preliminary extractions with $\mathrm{NH}_{4} \mathrm{Cl}$ and $\mathrm{NH}_{4} \mathrm{~F}$ using a 2 chamber device (i. e. a system in which mud and algae are in 2 different compartments, separated by a membrane), without aeration. They found that anoxic P-release was strongly related to the $\mathrm{P}_{\rightarrow \mathrm{NaOH}}$-concentration in the sediments and, furthermore, that about $30 \%$ of this phosphate was used by the algae. Tot-P decrease was identical to the decrease in $\mathrm{P}_{\rightarrow \mathrm{NaOH}}$. These results are similar to ours from Lake Vechten, where $\mathrm{P}_{\rightarrow \mathrm{NaOH}}$ was not depleted either. Most likely this is the part of org-P hydrolysed by the $\mathrm{NaOH}(0.1 \mathrm{M}, 17 \mathrm{hr}$ shaking).

Premazzi \& Zanon (1984) found that about $12 \%$ of Tot-P of sediments of Lake Lugano was available for algae and that the $\mathrm{P}_{\rightarrow \mathrm{DCB}}$ plus the
$\mathrm{P}_{\rightarrow \mathrm{NaOH}}$ was used by the algae, but only a minor portion of the $\mathrm{P}_{\text {acid }}$.

In a review Sonzogni et al. (1982) summarizing studies on sediments from the Great Lakes (USA), considered $\mathrm{P}_{\mathrm{aa}}$ to be equal to the sum of o-P plus $\mathrm{P}_{\rightarrow \mathrm{NaOH}}$ according to the Williams et al . $(1976,1980)$ extraction technique. They considered $0.1 \mathrm{M} \mathrm{NaOH}$ to give a better agreement than $1.0 \mathrm{M} \mathrm{NaOH}$, however, they neither examined the influence of the extraction time nor of the $\mathrm{NaOH}$ concentration, but mentioned the influence of the sediment/solution ratio; they recorded the degree of several extractions as "incomplete', 'complete', or 'none', but did not give the criteria for these degrees. In the next review Hegemann et al. (1983) concluded that bioassay techniques used so far do not measure all the $\mathrm{P}_{\mathrm{aa}}$ and that the extraction techniques present no evidence that all the chemically extracted $\mathrm{P}$ in these fractions is bioavailable. These authors pointed at the difficulty of using membranes to separate algae from sediments, i.e. the slow diffusion from the mud to the algal compartment and criticized the estimation of chlorophyll a as a measure of P-uptake. They suggested that protocols for long term experiments should be established, but did not give a solution for the problem of the growth of fungi under such circumstances.

Studiyng 27 different, but all noncalcareous, soils in the USA, Wolf et al. (1985) assumed that $\mathrm{P}_{\rightarrow \mathrm{NaOH}}$ equalled $\mathrm{P}_{\mathrm{aa}}$. They tested the so-called equilibrium phosphorus concentration (EPC), i. e. the o-P concentration where there is no net gain or loss of $\mathrm{P}$ from the solution in a sediment suspension. This EPC was then compared with different, rather classical, soil-P extraction techniques $\left(\mathrm{NaHCO}_{3}\right.$ and acid fluoride). They showed strong correlations between different fractions and bioavailability, which correlations improved when soils were grouped together according to geographic location and taxonomic classification. Although the correlations were strong indeed, $\mathrm{P}_{\mathrm{aa}}$ and $\mathrm{P}$-extracted were not iden-

\footnotetext{
${ }^{2)}$ In the discussion comparing their method with that of Williams, Hieltjes \& Lijklema changed the sequence of $\mathrm{NaOH}$ and $\mathrm{CDB}$ in the Williams method.
} 
tical, the former fraction being 2 - 6 times higher than the latter one. As these soils did not include calcareous soils, $\mathrm{Fe}(\mathrm{OOH}) \approx \mathrm{P}$ and org-P are the only phosphates present, which will both be only partially extracted by the alkaline extractants. The classical P-soil extraction techniques do not offer an alternative for measuring $\mathrm{P}_{\mathrm{aa}}$.

Young and DePinto (1982) using a two chamber system (i.e. separating algae and sediment by a membrane) found that the $\mathrm{P}_{\mathrm{aa}}$ ranged between 0 and $40 \%$ of $\mathrm{P}_{\text {part }}$ and correlated best with the $\mathrm{P}_{\rightarrow \mathrm{NaOH}}$. They found the following correlation between $\mathrm{P}_{\rightarrow \mathrm{NaOH}}$ and $\mathrm{P}_{\mathrm{aa}}$ :

$\mathrm{Y}=1.08 \mathrm{X}-0.008(\mathrm{r}=0.79)$, but between $\mathrm{P}_{\rightarrow \mathrm{NaOH}}$ plus $\mathrm{P}_{\rightarrow \mathrm{CDB}}: \mathrm{Y}=0.692 \mathrm{X}-0.07(\mathrm{r}=0.84)$. From the point of view of chemical fractionation this makes no sense: by setting $X$ equal to the sum $\mathrm{P}_{\rightarrow \mathrm{NaOH}}$ plus $\mathrm{P}_{\rightarrow \mathrm{CDB}}$, the slope becomes less, while the negative values at low P-concentrations are incomprehensible. The authors concluded, correctly, that "among the various chemical fractions of $\mathrm{P}_{\text {part }}$ which were compared to available fractions, no single fraction emerged which would quantify as a broadly-applicable surrogate and, thus, obviate the need to perform time-consuming bio-assays". This is certainly true for the period before chelating extractions were used.

Ekholm (1994), studying the availability of $\mathrm{P}_{\text {part }}$ in Finnish rivers, improved the 2 chamber method greatly: the algal medium was buffered at $\mathrm{pH}=7$ and the assay chamber was aerated (to avoid an increase in $\mathrm{pH}$ which would cause a change of P-fractions). Ekholm found that the $\mathrm{P}_{\text {aa }}$ ranged between 0 and $13.2 \%$ of $\mathrm{P}_{\text {part }}$ (mean value $5.1 \%$ ) in the river, and $2.6 \%$ in the sedimenting material, but $0 \%$ of the bottom sediment. Ekholm attributed this low percentage to the high adsorbing ability of Finnish acid mineral soils; this effect may well be enhanced by having mud and algae in separate chambers. The percentage bioavailable is, however, not lower than we found in humic rich L. Loosdrecht sediments. Ekholm tested the diffusion rate through the membrane by using $\mathrm{KH}_{2} \mathrm{PO}_{4}$ instead of mud. It must be remarked, however, that this does not give a good idea of the diffusion barrier, because the o-P-concentration is much lower in the pre- sence of adsorbing sediment than with $\mathrm{KH}_{2} \mathrm{PO}_{4}$ while the release rate from the particles may play a role as well.

Boers et al. (1984), using the Hieltjes \& Lijklema extraction procedure, found that the $\mathrm{P}_{\text {aa }}$ in humus rich sediments from L. Loosdrecht was much less than the $\mathrm{P}_{Æ N a O H}$ and was nearer to the 'loosely bound' pool, i.e. a few percent of Tot-P. Their results agreed with those of Golterman $e t$ al., (1969), but the authors did not investigate whether any further, slow, growth still continued; neither growth curves, nor a description of the methodology used, were given.

\section{CONCLUSIONS}

The bioavailability of P-compounds in sediments for algal growth remains a research topic where much has still to be done. Chemical fractionation techniques are better advanced, but for both areas of research the function of org-P remains to be clarified. Bio-assays are at the moment the only method to give some insight into the availability of $P_{\text {sed }}$, but must be replaced for routine work by a chemical fractionation. Only chelating extractants at the same $\mathrm{pH}$ as the sediment can give reliable results, but the presence of detrital apatite still presents a difficulty. Especial attention is needed for the presence, structure and function of humic-P and phytate.

\section{LINKS WITH THE N CYCLE}

There is a strong link between $\mathrm{P}$ in sediments and denitrification

Normally denitrification is described as:

$\underset{+}{\text { organic matter }}+\mathrm{HNO},--->\mathrm{CO},+\mathrm{N}$,
$\mathrm{H}_{2} \mathrm{O}+\Delta \mathrm{N}_{\text {bact }}$

but Golterman $(1991,1995)$ found that in shallow lakes or marshes FeS was preferred as reducing agent (reductant?) and showed that the amount of 
HNO, reduced was roughly equal to the amount of $\mathrm{SO}_{4}{ }^{2-}$ produced. $\mathrm{He}$ proposed the following reaction:

$5 \mathrm{FeS}+9 \mathrm{HNO},+3 \mathrm{H}_{2} \mathrm{O}--->5 \mathrm{Fe}(\mathrm{OOH})$

$+5 \mathrm{H}_{2} \mathrm{SO}_{4}+4.5 \mathrm{~N}$,

It seems likely, that the reducing power of the $\mathrm{Fe}^{2+}$ will also be used, although it is not certain.

There are two consequences of reaction (4) occurring instead of reaction (3). Firstly, denitrification increases the P-fixing capacity of the sediments by increasing the concentration of $\mathrm{FeOOH}$ and, more important probably, because a thin layer of $\mathrm{FeS}$ around the $\mathrm{FeOOH}$ particle may inhibit the passage of $\mathrm{P}$ towards the $\mathrm{FeOOH}$. Furthennore, there is a small increase in (4) in acidity which in calcareous sediments will shift the equilibrium between $\mathrm{Fe}(\mathrm{OOH}) \approx \mathrm{P}$ and $\mathrm{CaCO}_{3} \approx \mathrm{P}$.

Secondly, in reaction (4) a part of the HNO, is fixed as bacterial-N, thus enriching the sediments with $\mathrm{N}$. This may not be the case in (3), where the increase in $\mathrm{N}_{\text {bact }}$ may be derived from mineralized org-N from the sediments.

The formation of FeS under anoxic conditions does, however, not mean a release of $\mathrm{P}$ from the $\mathrm{Fe}(\mathrm{OOH}) \approx \mathrm{P}$ complex. (Golterman, 1995; Golterman, 2001). In the first place the amount of reducing capacity in lakes is usually too small to reduce a considerable quantity of the $\mathrm{FeOOH}$ present, and in the second place $\mathrm{Fe}(\mathrm{OOH}) \approx \mathrm{P}$ is a stronger complex than $\mathrm{FeOOH}$, so that it needs more energy to reduce $\mathrm{Fe}(\mathrm{OOH}) \approx \mathrm{P}$ than the excess $\mathrm{FeOOH}$ itself.

\section{Modelling denitrification}

In order to quantify the influence of denitrification on P-binding onto sediments it is necessary to quantify, or model, the denitrification. Golterman (2000) showed, however, that modelling the denitrification process is tedious. The controlling system-constants are the molecular diffusion constant, an acceleration factor describing eddy diffusion, and three bacterial growth constants, viz. the inoculum size, the maximum growth rate and the half saturation constant for the hyperbolic process. The values of these system-constants may vary over a wide range resulting in rather different $\mathrm{HNO}$, decrease curves; therefore, no prediction is possible as long as these system-constants are not known. This interaction of $\mathrm{P}$ - and $\mathrm{N}$-cycles renders modelling of $\mathrm{P}$ release from and adsorption onto sediments impossible for the time being.

\section{ACNOWLEDGEMENT}

The author acknowledges the help of Dr L. Serrano and Ir N. T. de Oude with this manuscript and that of Mrs J. C. Golterman - Hardenberg with improving the English.

\section{REFERENCES}

BARBANTI, A., M.C. BERGAMINI, F. FRASCART, S. MISEROCCHI \& G. ROSSO. 1984. Critica1 aspects of sedimentary phosphorus chemical fractionation. J. Env. Qual., 23: 1093 - 1102

BOERS, P. C. M., J. W. TH. BONGERS, A. G. WISSELO \& TH. E. CAPPENBERG. 1984. Loosdrecht Lakes restoration projekt: Sediment phosphorus distribution and release from the sediments. Verh. Int. Ver:Limnol., 22: 842 - 847

BOSTROM, B., G. PERSSON \& B. BROBERG. 1988. Bioavailability of different phosphorus forms in freshwater systems. Hydrobiologia, 170: 133 155

BRUNING, C. \& S. P. KLAPWIJK. 1984.Application of derivative spectroscopy in bioassays estimating algal available phosphate in lake sediments. Verh. Int. Ver.Limnol., 22: 172 - 178

BURKE, A. J., P. A. WALLER \& W. F. PICKERING. 1989. The evaluation of inorganic phosphate species in salt water lake sediments. Chem. Speciation and Bioavailability, 1: 47 - 57

CHANG, S. C. \& M. L. JACKSON. 1957. Fractionating of soil phosphorus. Soil Sci. 84: 133 144.

DE GRAAF BIERBRAUWER-WÜRTZ, I. M. \& H. L. GOLTERMAN. 1989. Fosfaatfracties in de bodem van een aantal Nederlandse meren. (in Dutch, with English summary). $\mathrm{H}_{2} \mathrm{O}, 22: 411$ - 414 
DE GROOT, C. J. 1990. Some remarks on the presente of organic phosphates in sediments. Hydrobiologia, 207: 303- 309.

DE GROOT, C. J. \& H.L. GOLTERMAN. 1990. Sequential fractionation of sediment phosphate. Hydrohiologiu, 192: 143-148

DE GROOT, C. J. \& H.L. GOLTERMAN. 1993. On the presence of organic phosphate in some Camargue sediments : evidence for the importance of phytate. Hydrohiologia, 252, $117-126$.

DORICH, R. A., D. W. NELSON \& L. E. SOMMERS. 1984. Availability of phosphorus to algae from eroded soil fractions. Agriculture, Ecosystems and Environment, 11: 253 - 264.

DORICH, R. A., D. W. NELSON \& L. E. SOMMERS. 1985. Estimating algal available phosphorus in suspended sediments by chemical extraction. J. of Environm. Quality, 14: $400-405$

EKHOLM, P. 1994. Bioavailability of phosphorus in agricultura1 loaded rivers in southern Finland. Hydrobiologia, 287: $179-194$

FABRE, A., A. DAUTA, A. QOTBI \& V. BALDY. 1996. Relation between algal available phosphate in the sediments of the River Garonne and chemically determined phosphate fractions. Hydrobiologia, 335: 43 - 48

GOLTERMAN, H.L., 1977. Sediments as a source of phosphate for algal growth. In: Interactions between sediments and fresh water; Proceedings oj an International Symposium held at Amsterdam, 6 10 September 1976. H.L. Golterman (ed.): 286293. The Hague, Junk; Wageningen, PUDOC.

GOLTERMAN, H. L. 1982. Differential extraction of sediment phosphates with NTA solutions. Hydrohiologia, 92: 683 - 687.

GOLTERMAN, H. L. 1991. The influence of FeS on the denitrification rate. Verh. Int. Ver. Limnol., 23: 3025 3028

GOLTERMAN, H. L. 1995. The labyrinth of nutrient cycles and buffers in wetlands: results based on research in the Camargue (Southern France). Hydrobiologia, 315: 39-58

GOLTERMAN, H. L. 1995. The role of the ironhydroxide-phosphate-sulphide system in the phosphate exchange between sediments and overlying water. Hydrobiologiu, 297: 43-54

GOLTERMAN, H. L. 1996. Fractionation of sediment phosphate with chelating compounds: a simplification, and comparison with other methods. Hydrobiologiu, 335: 87 - 95
GOLTERMAN, H. L. 1998. The distribution of phosphate over iron-bound and calcium-bound phosphate in stratified sediments. Hydrobiologia, 364: $75-81$.

GOLTERMAN, H. L. 2000. Denitrification and a numerical modelling approach for shallow waters. Hydrohiologiu, 431: 93 - 104

GOLTERMAN, H. L. 2001. Phosphate release from anoxic sediments. Hydrohiologia, 450: 99-106.

GOLTERMAN, H. L., C. C. BAKELS \& J. JAKOBSMOGELEIN. 1969. Availability of mud phosphates for the growth of algae. Verh. int. Vez Limnol., 17: 467-479.

GOLTERMAN, H. L \& A. BOOMAN. 1988. Sequential extraction of iron-phosphate and calcium- phosphate from sediments by chelating agents. Verh. Int. Vez Limnol., 23: 904 - 909

GOLTERMAN H.L., J. PAING, L. SERRANO, E. GOMEZ. 1998. Presence of and phosphate release from polyphosphates or phytate phosphate in lake sediments. Hydrohiologiu, 364: 99 - 104

GROBBELAAR, J. U. 1983. Availability to algae of N and $\mathrm{P}$ adsorbed on suspended solids in turbid waters of the Amazon River. Arch. Hydrobiol., 96: 302-316

GROBLER, D. C. \& E. DAVIES. 1979. The availability of sediment phosphate to algae. Water S.A., 5: $114-123$.

GROBLER, D. C. \& E. DAVIES. 1981. Sediments as a source of phosphate; A study of 38 impoundments. WaterS.A., 7: 54 - 60

HEGEMANN, D. A., A. H. JOHNSON \& J. D. KEENAN. 1983. Determination of Algal-available Phosphorus on Soil and Sediment: A Review and Analysis. J. Environ. Qual., 12: 12 - 16

HIELTJES, A. H. M. \& L. LIJKLMA, 1980. Fractionation of inorganic phosphates in calcareous sediments. J. Envir. Qual., 9: 405-407.

HOSOMI, M., M. OKADA \& R, SUDO, 1981. Release of phosphorus from sediments. Verh. Int. Ver: Limnol., 21: 628 - 633

HOUSE, W. A., F. H. DENISON \& P. D. ARMITAGE. 1995. Comparison of the uptake of inorganic phosphorus to a suspended and stream bed-sediment. Water-Res., 29: 767-779.

HUETTL, R. C., WENDT, R. C. \& R. B. COREY. 1979. Prediction of algal-available phosphorous in runoff sediments. J. Env. Qual., 8: 130- 132

HUPFER, M., R. GACHTER \& H. RÜEGGER. 1995. Polyphosphate in lake sediments: 31P NMR spectrospcopy as a tool for its identification. Lirnnol. Oceanogr., 40: 610 - 617 
JACKSON, M. L. 1958. Soil chemical analysis. Englewood Cliffs, Prentice Hall. 498 pp.

JÁUREGUI, J. \& J. A. GARCÍA SANCHEZ. 1993. Fractionation of sedimentary phosphorus: A comparison of four methods. Verh. Int. Ver: Limnol. 25: $1150-1152$

KLAPWIJK, S. P. \& C. BRUNING. 1984. Available Phosphorus in the Sediments of Eight Lakes in the Netherlands. Proceedings of the Third International Symposium on Interactions Between Sediments and Water. P Sly (ed.): 391 - 398. Springer Verlag.

PETTERSON, K., B. BOSTROM \& 0.-S. JACOBSEN. 1988. Phosphorus in sediments - speciation and analysis. Hydrobiologia, 170: 91-101

PREMAZZI, G. \& G. ZANON, 1984. Availability of sediment $\mathrm{P}$ in Lake Lugano. Verh. Int. Ver:Limnol., 22: 1113 - 1118.

PSENNER, R., R. PUCSKO \& M. SAGER. 1985.Die fractionierung organischer und anorganischer Phosphorverbindungen von Sedimenten. Arch. Hydrobiol./Suppl., 70: $111-155$.

PSENNER, R. \& R. PUCKSO. 1988. Phosphorus fractionation: advantages and limits of the method for the study of sediment P origins and interactions. Arch. Hydrobiol. Beih. Ergeb. Limnol., 30: 43 - 59

ROMERO-GONZALEZ, M. E., E. ZAMBRANO, J. MESA \& H. LEDO DE MEDINA. 2001 . Fractional composition of phosphorus in sediments from a tropical river (Catatumbo river, Venezuela. Hydrobiologia, 450: 47-55.

RUTTENBERG, K. C. 1992. Development of a sequential extraction method for different forms of phosphorus in marine sediments. Limnol. Oceanogr., 37: 1460-1482

SONZOGNI, W. C., S. C. CHAPRA, D. E. ARMSTRONG \& T. J. LOGAN. 1982. Bioavailability of Phosphorus lnputs to Lakes. J. Environ. Qual., 11:555-563

WALLER, P.A. \& W. F. PICKERING. 1992. Determination of 'labile' phosphate in lake sediments using anion exchange resins: a critical evaluation. Chem.-Speciation-Bioavailab., 4(2): 59-68

WILLIAMS, J. D. H., J. M. JAQUET \& R. L. THOMAS. 1976. Forms of phosphorus in the surficial sediments of Lake Erie. J. Fish. Res. Bd. Can., 33: $430-439$

WILLIAMS, J. D. H., H. SHEAR \& R. L. THOMAS. 1980. Availability to Scenedesmus quadricauda of different forms of phosphorus in sedimentary materials from the Great Lakes. Limnol. Oceanogr., 25: $1-11$

YOUNG, T. C. \& J. V. DEPINTO, 1982. Algal-availability of particulate phosphorus from diffuse and point sources in the lower Great Lakes Basin. Hydrobiologia, 91: 11 1-119. 